\title{
Synthesis of glue used for the purpose of sticking plastics on the base of Cyklopol process waste fraction
}

\author{
Otmar Z. Vogt ${ }^{1^{*}}$, Elżbieta L. Vogt ${ }^{2}$, Witold J. Charyasz ${ }^{3}$ \\ ${ }^{1}$ Cracow University of Technology, Institute of Chemistry and Organic Technology, ul. Warszawska 24, 31-155 Kraków, \\ Poland \\ ${ }^{2}$ AGH University of Science and Technology, Faculty of Fuels and Energy, Al. Mickiewicza 30, 30-059 Kraków, Poland \\ ${ }^{3}$ JAGO-PRO Sp. z o.o., ul. Szczakowska 35, 43-600 Jaworzno, Poland \\ "corresponding author: e-mail: ozvogt@chemia.pk.edu.pl
}

\begin{abstract}
The utilization of monohydric alcohols waste fraction from the Cyklopol process was studied. On the basis of this fraction the solvent, which mainly contains acetic acid esters, was synthesized. Tests of the application of the obtained solvent as a base of glue for plastics were carried out and it was found out that it could be used to stick PMMA together. In the case of PS, PET, PC or PVC slightly weaker sticking properties of this solvent also occurred. The glue joint characteristics in the case of PMMA were similar to those obtained for the glue joints that were made with the use of the commercially available glue used for this plastic. The additional advantage of our glue is its nice fruity smell.

The obtained results enable us to establish the possibility of waste alcohol fraction management as a raw material for the production of glue for plastic. The esterification method proposed in the work can be a good way of management of waste alcohol fractions naturally occurring during cyclohexanone production.
\end{abstract}

Keywords: Cyklopol, waste alcohol fraction, glue for plastic.

\section{INTRODUCTION}

According to recent knowledge concerning the environment protection, it would be better to look for new ways of the utilization of an industrial waste than to combust it ${ }^{1}$.

The production methods of a PVC plasticizer ${ }^{2,3}$, surfactants ${ }^{4}$, paint and lacquer solvents or smell additives were carried out during our research on the utilization of the selected waste products from the Cyklopol process (the cyclohexanone production process). Household chemicals were also produced on the base of these substances. A test of the obtained solvent for glues that stick to plastic, was taken into consideration in this work.

\section{EXPERIMENTAL}

The research was carried out at the Department of Organic Technology and Refinery Process at the Cracow University of Technology or at the Faculty of Fuels and Energy at the AGH University of Science and Technology. In this work, dehydrated waste alcohol fraction from the Cyklopol plant (The Company: Zakłady Azotowe in Tarnów-Mościce S.A.) was used as the main raw material. The average composition of the investigated fraction is shown in Table 1 . The water content in the raw fraction does not exceed $3 \%$ mass. Acetic acid anhydride was used as an esterification agent.

The sticking properties of the obtained glues were examined with the use of the selected plastics: polyvinyl chloride $(\mathrm{PVC})$, polypropylene $(\mathrm{PP})$, polyethylene $(\mathrm{PE})$, polystyrene (PS), polyethylene terephthalate (PET), polycarbonate (PC),

Table 1. The average composition of the dehydrated waste alcohol fraction

\begin{tabular}{|l|c|l|c|}
\hline Agent & {$[\%$ mass $]$} & Agent & {$[\%$ mass $]$} \\
\hline hydrocarbons to $\mathrm{C}_{7}$ & 0.82 & propanol & 1.10 \\
\hline ketones $\mathrm{C}_{3}-\mathrm{C}_{6}$ & 12.90 & butanol & 11.00 \\
\hline aldehydes $\mathrm{C}_{5}-\mathrm{C}_{6}$ & 3.88 & pentanol & 58.40 \\
\hline others & 2.80 & $\begin{array}{l}\text { cyclic alcohols } \\
\mathrm{C}_{5}-\mathrm{C}_{6}\end{array}$ & 9.10 \\
\hline
\end{tabular}

Poly(methyl methacrylate) (PMMA), high-density polyethylene (HDPE) and low-density polyethylene (LDPE). The material samples were characterized by a flat and smooth surface, the lack of coloured additives and a stiff structure.

\section{The solvent synthesis}

The alcohol fraction was esterified by acetic acid anhydride. The $25 \%$ excess of the alcohol fraction in relation to acetic acid anhydride (in terms of pentanol) was used in the reaction. The process was carried out for about 6.5 hours in the presence of sulphuric acid ( $2 \%$ mass) as a catalyst, at the temperature of $380-400 \mathrm{~K}$. The distillation process was applied in order to separate the extraction products from the solution. The boiling temperature of the obtained fraction was in the range of 370 to $433 \mathrm{~K}$. It was characterized by a straw colour and fruity smell. The residue after the process was about $14.1 \%$ mass from the distillation charge.

The residual acetic acid present in the products was removed by multistage water extraction. The $\mathrm{pH}$ of the product changed from the initial value of 3 to the final value of 5. The improvement in colour and smell was observed simultaneously. The density of the organic phase measured by a pycnometric method at the temperature of $295 \mathrm{~K}$ is $0.889 \mathrm{~g} / \mathrm{cm}^{3}$. The volatility ${ }^{5}$ of the solvent towards amyl acetate is 0.969 .

The chromatographic analysis of the obtained products was performed by means of the Agilent $6890 \mathrm{~N}$ chromatograph equipped with 5975C inert XL MSD detector, HP5MS $0.25 \mu \mathrm{m}$ column $-30 \mathrm{~m}$ long. The obtained results show that amyl acetate is the main component of the analysed mixture. The product contains $66 \%$ of this substance. One of the chromatograms is shown in Figure 1.

\section{The investigation of plastics solubility}

The investigation results of solubility of the selected plastics in the obtained solvent are shown in Table 2. On the basis of these results suitable plastic materials for other investigations could be chosen. 
Table 2. The influence of the obtained solvent on the selected plastics

\begin{tabular}{|c|c|c|c|c|c|}
\hline \multirow[t]{2}{*}{ Selected sample } & \multirow{2}{*}{$\begin{array}{c}\text { Initial sample mass } \\
{[\mathrm{g}]}\end{array}$} & \multicolumn{3}{|c|}{$\begin{array}{c}\text { Observation of the change of the sample after its immersion in } \\
\text { solvent, after time }\end{array}$} & \multirow{2}{*}{$\begin{array}{c}\text { Mass loss of the sample after } \\
\text { one day } \\
{[\% \mathrm{wt}]}\end{array}$} \\
\hline & & 10 [min] & 30 [min] & $45[\mathrm{~min}]$ & \\
\hline PVC & 0.3848 & - & got soft & got crumbly & $18 \%$ \\
\hline $\mathrm{PP}$ & 0.1822 & - & - & - & $0 \%$ \\
\hline $\mathrm{PE}$ & 0.2659 & - & - & - & $0 \%$ \\
\hline PET & 0.1116 & - & - & - & $0 \%$ \\
\hline PS & 0.1151 & gluey & gluey & transparent solution & $100 \%$ \\
\hline $\mathrm{PC}$ & 0.7563 & - & got a little soft & got soft & - \\
\hline PMMA & 0.7999 & gluey & gluey & gluey solution & $14 \%$ \\
\hline HDPE & 0.5254 & - & - & - & $0 \%$ \\
\hline LDPE & 0.5228 & - & - & got a little soft & $0 \%$ \\
\hline
\end{tabular}

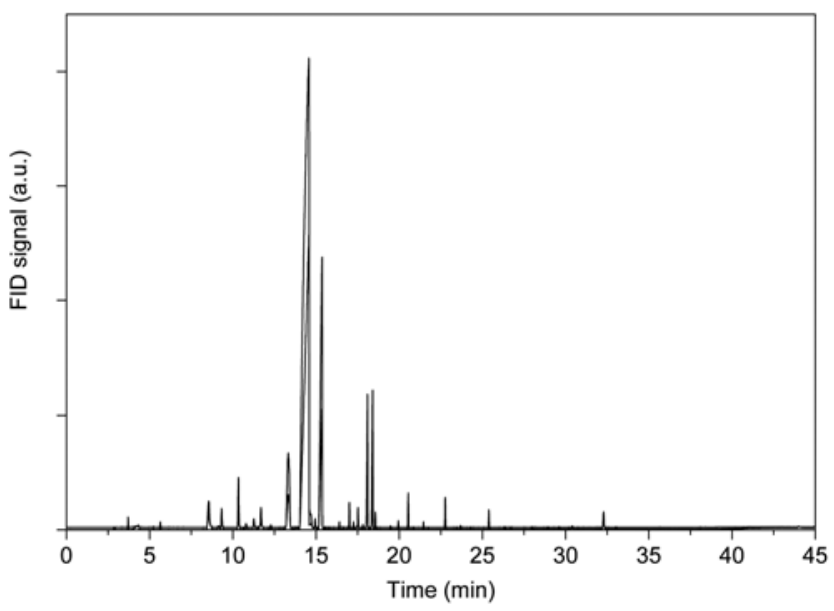

Figure 1. The chromatogram of the obtained solvent

\section{The sticking tests of selected plastics}

The selected samples prepared for sticking had a cubicoid shape and were characterized by the following dimensions: $45 \mathrm{~mm} \times 15 \mathrm{~mm}$ and thickness of $0.8 \mathrm{~mm}$. A weld area was $15 \times 15 \mathrm{~mm}$ when sticking tests were carried out. Mechanical impurities were cleaned off the plastic samples that were also degreased. The sticking process was performed in two ways: at room temperature and at a high temperature. In the case of cold sticking glue spreading was performed at the temperature of $295 \mathrm{~K}$ and the humidity of $65 \%$.

Hot sticking was carried out with the use of a solution made from selected plastics and an obtained solvent. The plastic solutions were heated to the boil. Then a thin layer of the hot solution was spread on a plastic and the weld was dried by a hot air stream for $10 \mathrm{~min}$.
During both cold and hot sticking the welds were loaded by $5 \mathrm{~kg}$ of weight. The glue quantity was sufficient to form the correct weld ${ }^{6}$. The results are shown in Table 3.

On the basis of the sticking tests results it was found that the used plastic solutions (a solvent and the plastics dissolved in it) formed the welds but these joints were rather undurable and a small force was sufficient to destroy them. Therefore, only some plastics (PMMA, PVC, PET, PC) were selected for a strength test. Although very good sticking results were observed in the case of PS, this plastic was not tested because the shape of available samples was not applicable for a shear test.

\section{Strength test of stuck plastics}

The shear test of the obtained welds was carried out ${ }^{6,7}$. The solutions of PMMA, PS and PVC were prepared. They were used as a glue for the selected plastics.

Table 4. Strength test results

\begin{tabular}{|c|c|c|c|c|}
\hline \multirow{2}{*}{ Stuck plastic } & \multirow{2}{*}{ solvent } & \multicolumn{3}{|c|}{ Sticking solution } \\
\cline { 3 - 5 } & & PMM & PS & PVC \\
\hline PVC & & + & & + \\
\hline PS & & + & + & \\
\hline PET & & + & + & \\
\hline PC & & + & & \\
\hline PMMA & + & + & & \\
\hline
\end{tabular}

According to the Polish standard ${ }^{\mathbf{6}}$, before the strength test the stuck samples were stored at the temperature of $296 \mathrm{~K}$, and the humidity was $65 \%$.

The shear test was carried out with the use of INSTRON 1115 apparatus equipped with a head of $0.5 \mathrm{t}$. The speed of

Table 3. The sticking tests results

\begin{tabular}{|c|c|c|c|c|c|c|c|c|}
\hline \multirow{3}{*}{ Stuck plastic } & \multicolumn{5}{|c|}{ Cold sticking } & \multirow{2}{*}{\multicolumn{3}{|c|}{$\begin{array}{l}\text { Hot sticking } \\
\text { plastic solution }\end{array}$}} \\
\hline & \multirow[t]{2}{*}{ solvent } & \multicolumn{4}{|c|}{ plastic solution } & & & \\
\hline & & own & PMMA & PS & PVC & PMMA & PS & PVC \\
\hline PVC & - & - & - & - & - & durable joint & - & durable joint \\
\hline $\mathrm{PP}$ & - & - & - & - & - & - & - & - \\
\hline $\mathrm{PE}$ & - & - & - & - & - & - & - & - \\
\hline PET & - & - & - & - & - & - & - & - \\
\hline PS & durable joint & durable joint & - & - & - & durable joint & $\begin{array}{c}\text { durable } \\
\text { joint }\end{array}$ & - \\
\hline PET & - & - & - & - & - & durable joint & $\begin{array}{c}\text { durable } \\
\text { joint }\end{array}$ & - \\
\hline $\mathrm{PC}$ & durable joint & - & undurable joint & undurable joint & - & durable joint & - & - \\
\hline PMMA & durable joint & durable joint & - & - & - & durable joint & $\begin{array}{c}\text { durable } \\
\text { joint }\end{array}$ & - \\
\hline HDPE & - & - & undurable joint & undurable joint & - & - & - & - \\
\hline LDPE & - & - & undurable joint & undurable joint & - & - & - & - \\
\hline
\end{tabular}




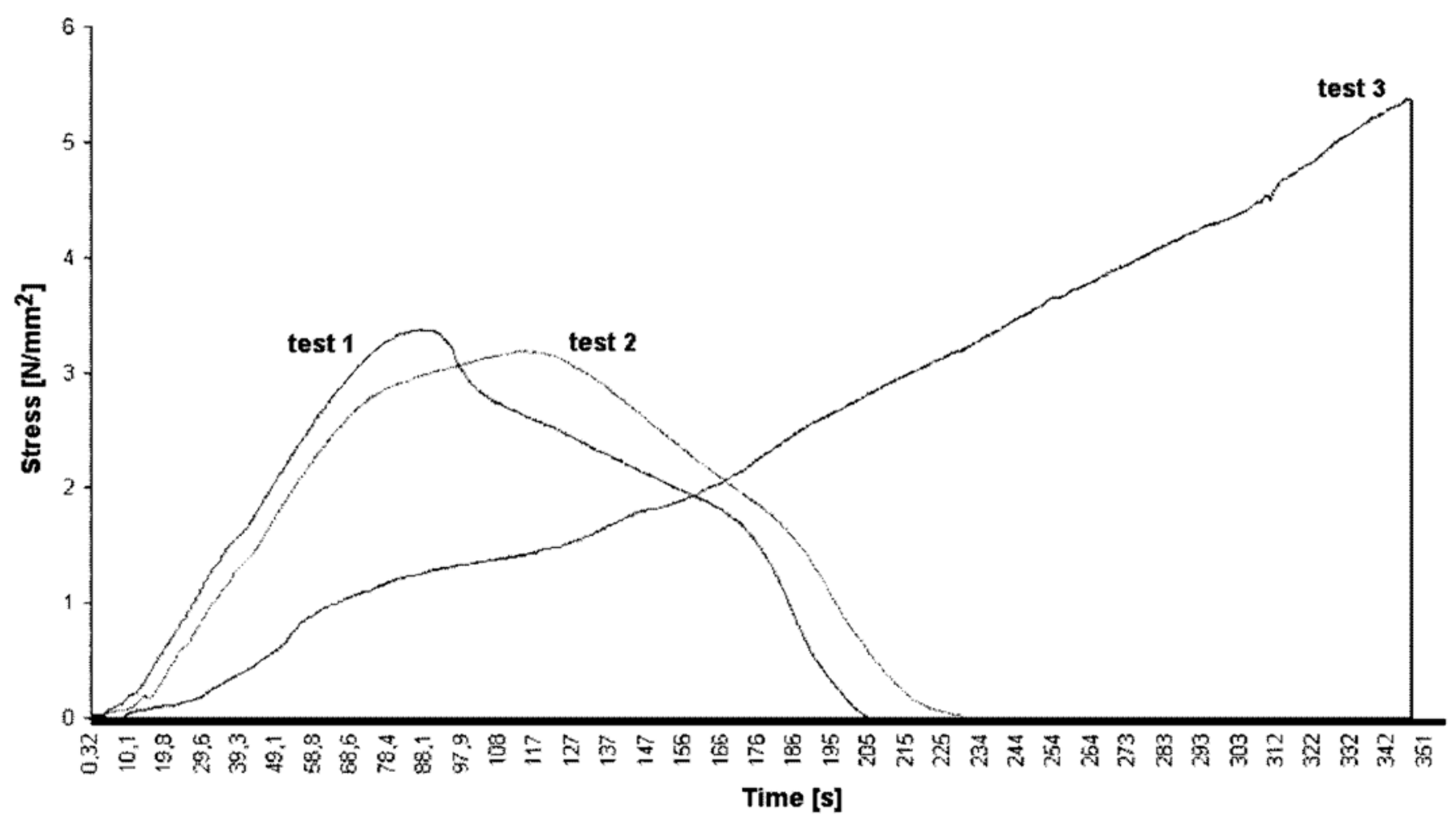

Figure 2. The relation between the stress value and time for PMMA - PMMA

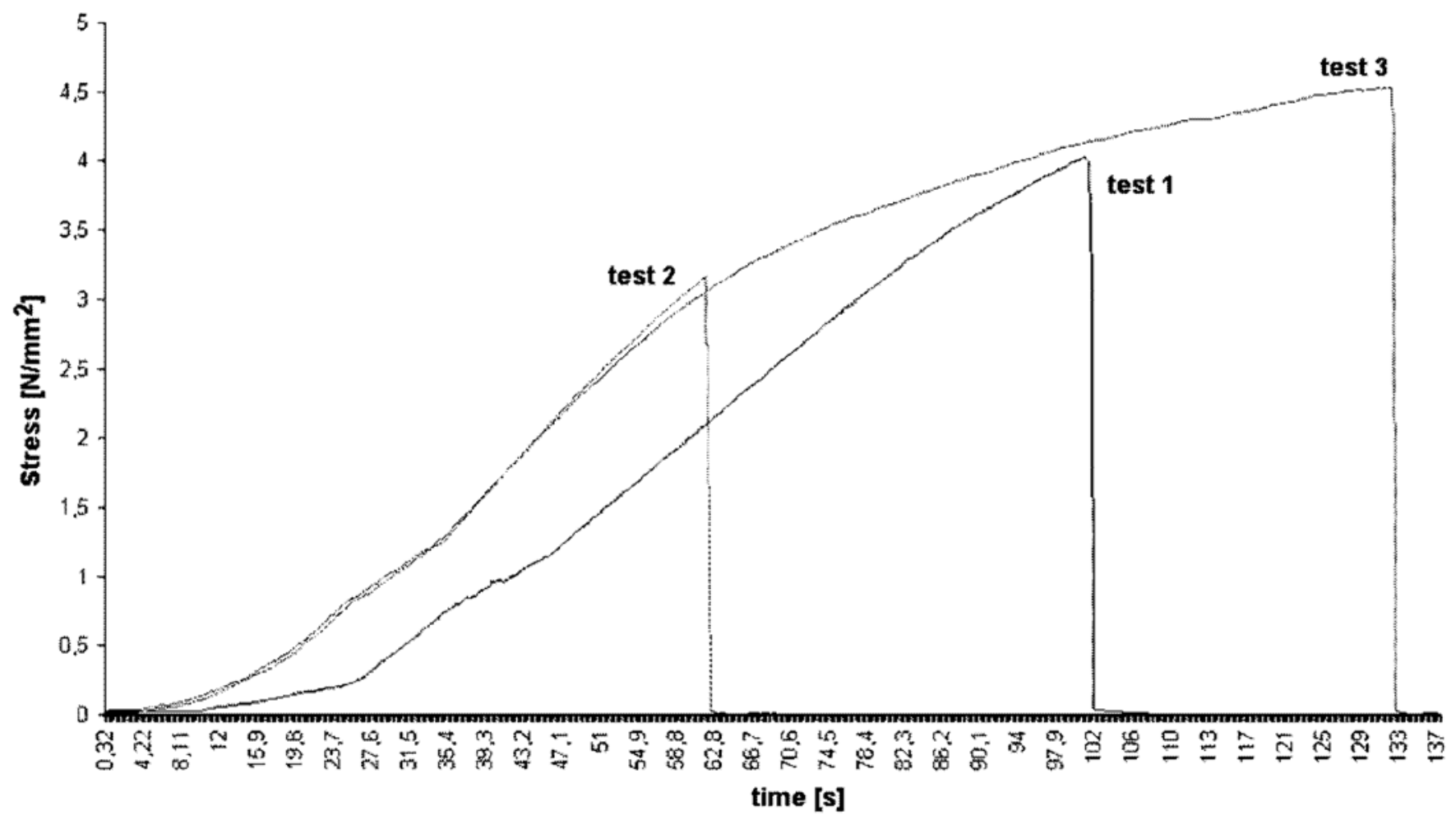

Figure 3. The relation between the stress value and time for the PMMA - solvent

tension was one mm per minute. The shear time, the value of shear force, stress and strain were registered. The shear tests results are shown in Figures $2-7$. The subtitles of Figures 2 - 7 mean:

PVC - PVC - pieces of PVC were stuck by its oven solution,

PMMA - solvent - pieces of PMMA were stuck by the solvent,

PVC - PMMA - pieces of PVC were stuck by the PMMA solution,
PET - PMMA - pieces of PET were stuck by the PMMA solution,

PET - PS - pieces of PET were stuck by the PS solution, PC - PMMA - pieces of PC were stuck by the PMMA solution,

PMMA - PMMA - pieces of PMMA were stuck by the PMMA solution.

The results, which are illustrated in Figures $2-7$, point to big strength of the PMMA - PMMA joint. The force action (742 N, time - $347 \mathrm{~s}$ ) caused damage to the plastic material but the weld was not destroyed. In two other tests 


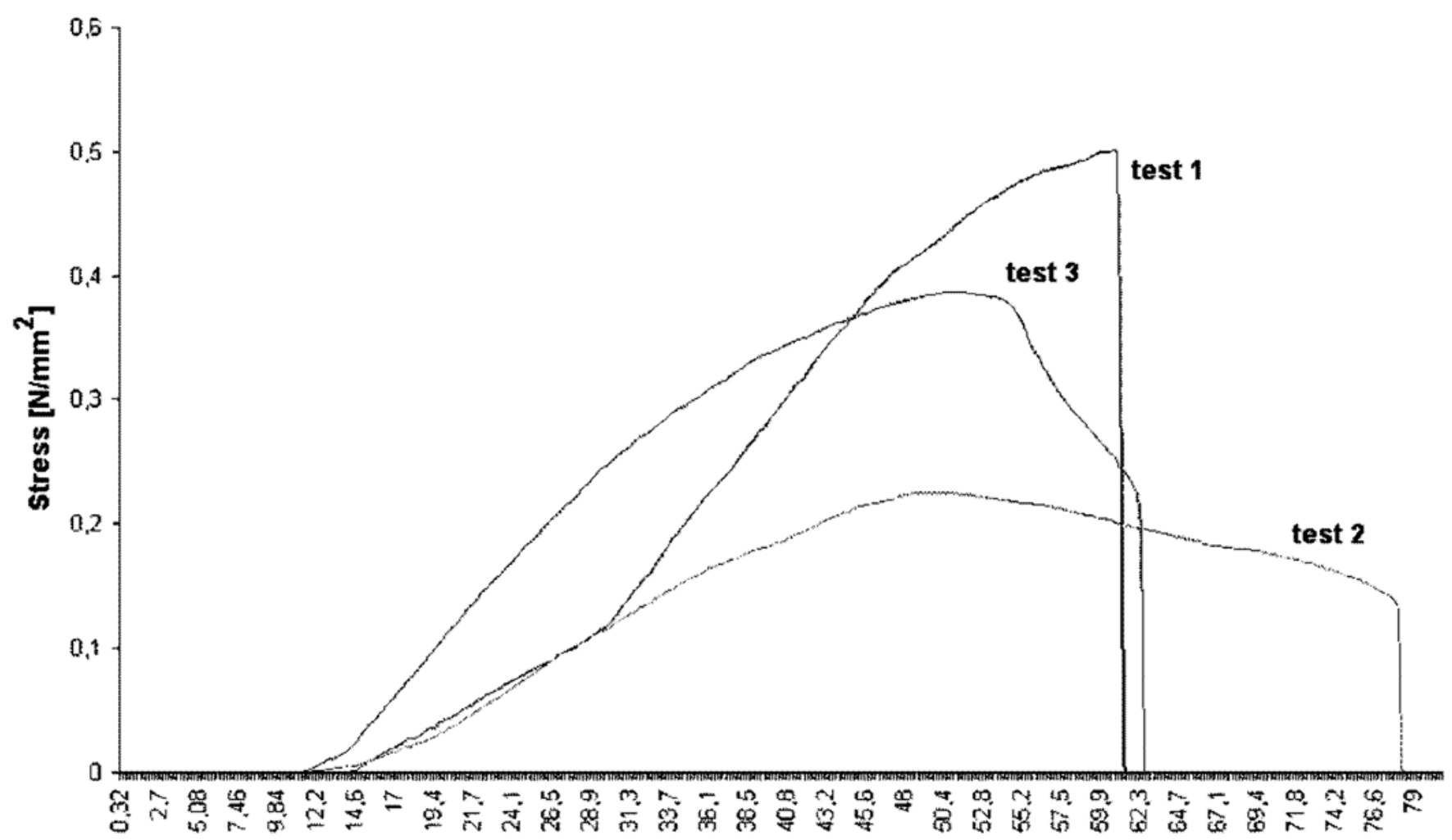

Figure 4. The relation between the stress value and time for PVC - PMMA

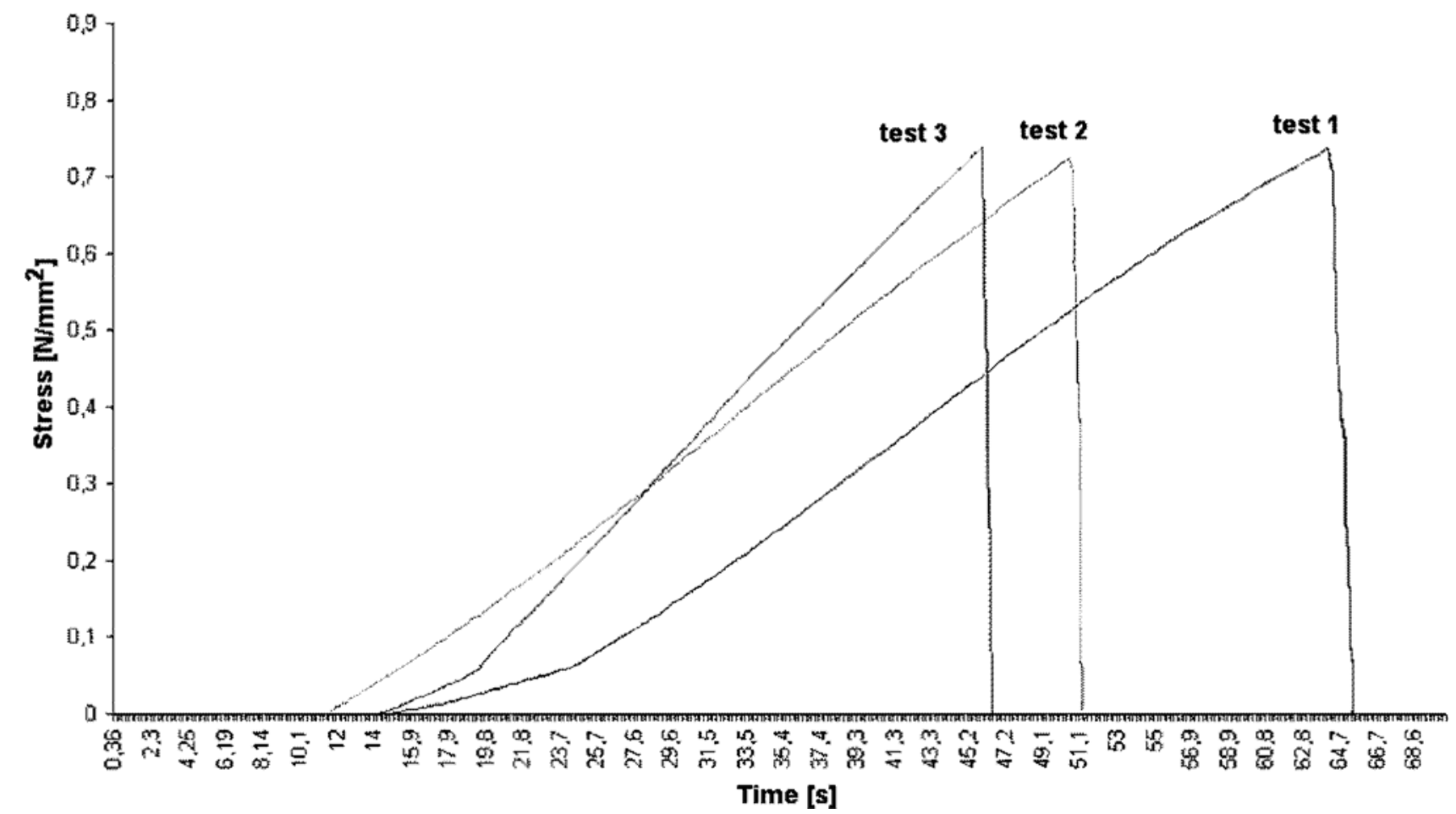

Figure 5. The relation between the stress value and time for PVC - PVC

the welds were destroyed at the force of $662 \mathrm{~N}$ (stress 3.18 $\mathrm{N} / \mathrm{mm}^{2}$ ) and $685 \mathrm{~N}$ (stress $3.36 \mathrm{~N} / \mathrm{mm}^{2}$ ).

During the strength test of the weld of PPM - solvent (Figure 3), the stuck material was damaged beyond the weld area whereas an appropriate sticking point did not fail. Sample 1 - stress $4.02 \mathrm{~N} / \mathrm{mm}^{2}$, force $804 \mathrm{~N}$, sample 2 - stress $3.16 \mathrm{~N} / \mathrm{mm}^{2}$, force $663 \mathrm{~N}$, sample 3 - stress $452 \mathrm{~N} / \mathrm{mm}^{2}$, force $870 \mathrm{~N}$. The obtained weld was transparent and did not get tarnished. This feature is an additional advantage of the obtained solvent.
Unfortunately it was stated that the weld PVC - PMMA is not durable (Figure 4). The low values of shear forces 104 $\mathrm{N}$ (stress 0.49 ), $42 \mathrm{~N}$ (stress 0.22 ), $82 \mathrm{~N}$ (stress 0.38 ) cause the damage to the welds. The similar situation occurred for PVC - PVC (Fig.5), PET - PMMA and PET - PS (Fig.6) welds. The PVC - PVC weld was damaged at the stress reaching 0.74 (force about $154 \mathrm{~N}$ ). In the case of the PET - PMMA and PET - PS welds the break-off took place when the stress amounted to about 0.14 (force about $22 \mathrm{~N}$ ). This weak result was undoubtedly caused by the presence of an air bubble inside the weld, which was difficult to remove. The 


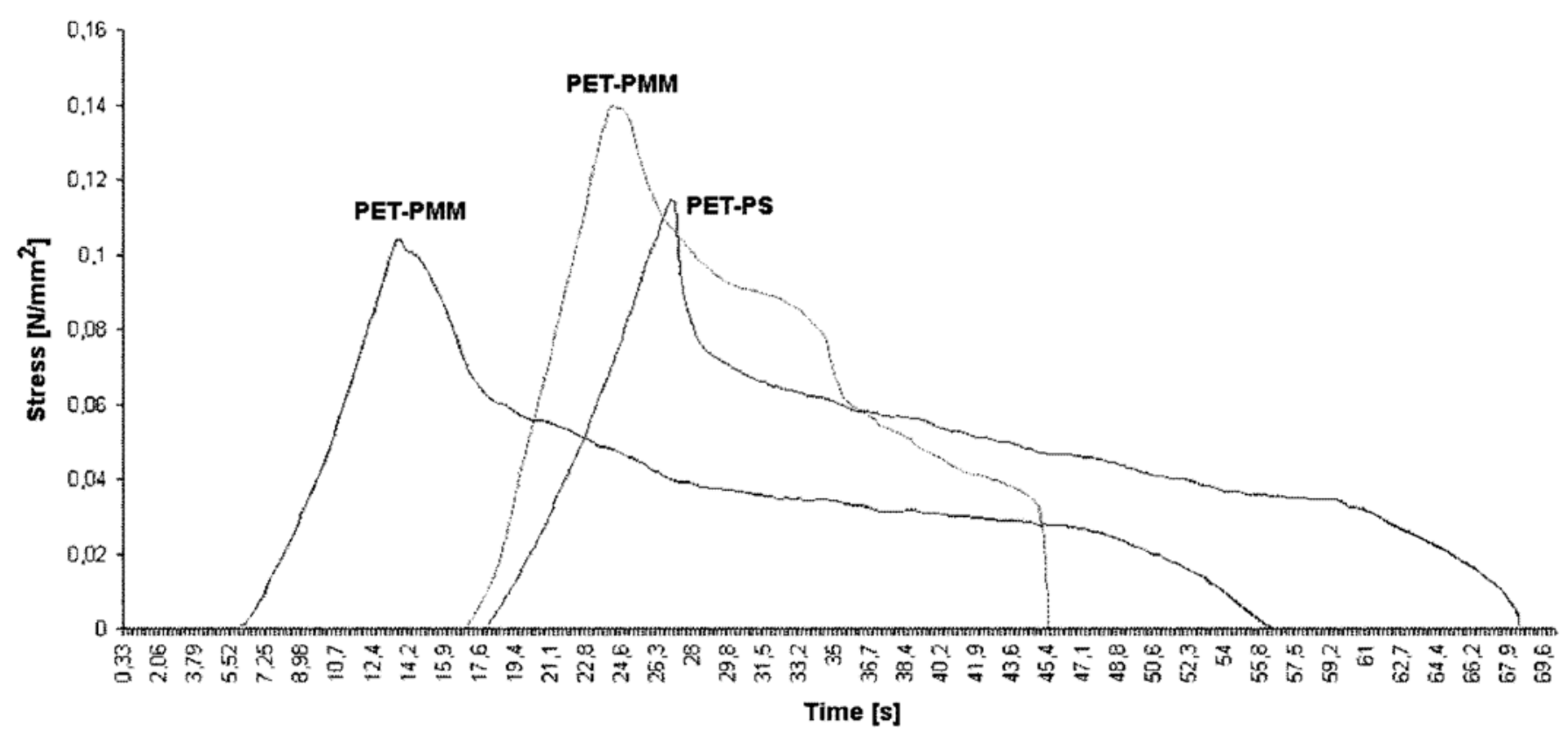

Figure 6. The relation between the stress value and time for PET - PMMA and PET - PS

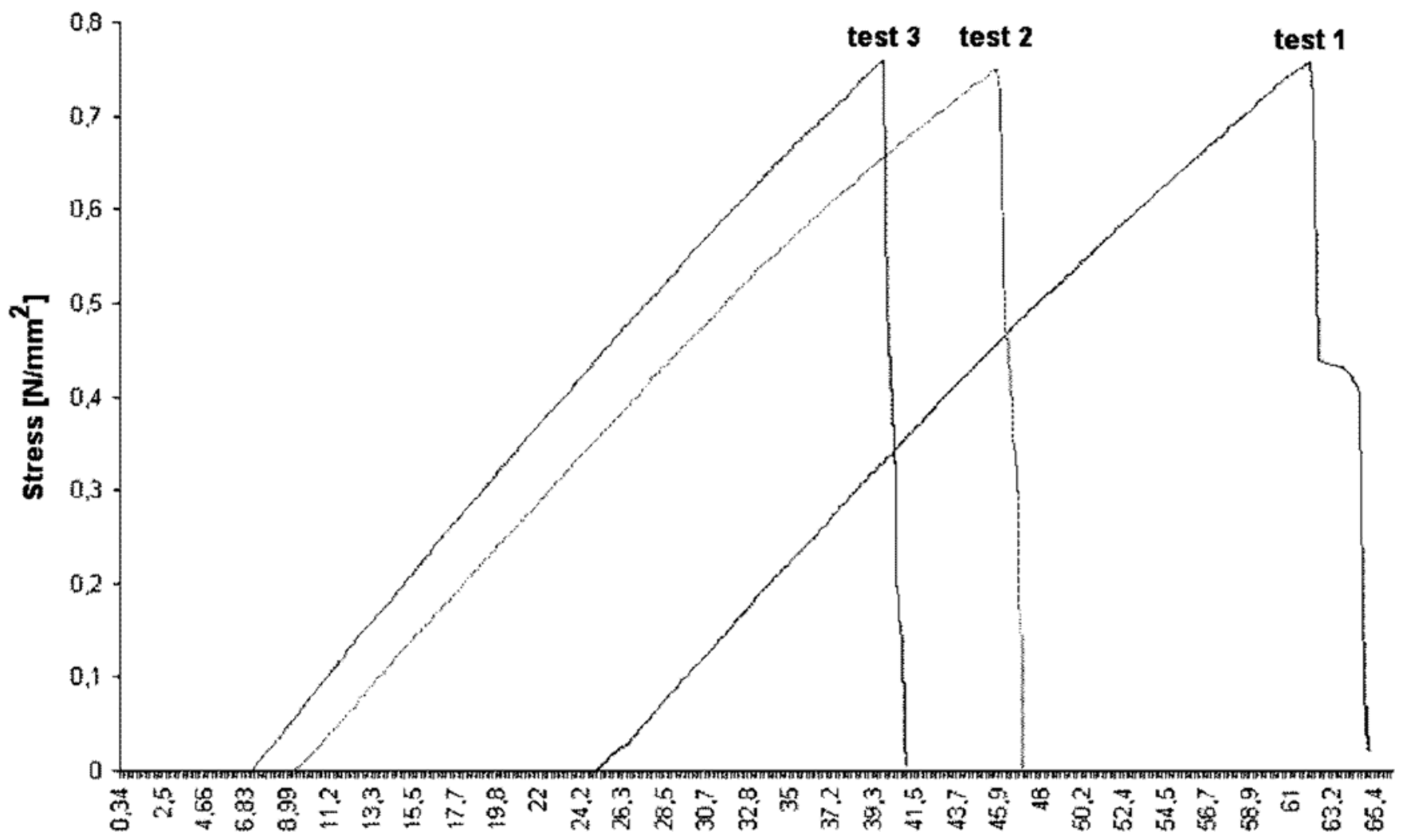

Time [s]

Figure 7. The relation between the stress value and time for PC - PMMA

results shown in Figure 7 (the relation between the stress value and time for PC-PMMA) do not illustrate good strength properties in the shear test. The damage to the weld took place at the stress value of about 0.75 and the force was $157 \mathrm{~N}$.

The authors wanted to check the resistance of the obtained welds for water. The shear test of the obtained welds after both water and thermal shock tests was carried out ${ }^{6,7}$. For this reason, the stuck plastic samples were immersed in water and heated in the bath $(296 \mathrm{~K})$ within 3 hours $^{8}$. For all the investigated samples no changes either in appearance or strength properties were noticed.
The thermal shock test ${ }^{7}$ consists in placing samples in water bath and heating them up to a temperature of $296 \mathrm{~K}$ for 30 minutes and later at a temperature of $393 \mathrm{~K}$. These activities were repeated four times. After these investigations it was found that the welds: PET - PS and PET - PMMA became damaged in the second cycle, PC - PMMA was not damaged but changed from transparent to milk-white colour, PS - PMMA and PS - PS did not get damaged, PVC PMMA and PVC - PVC became soft and damaged too, PMMA - PMMA and PMMA - solvent did not get damaged, but a small quantity of air bubbles appeared inside the weld after the fourth cycle. 


\section{CONCLUSIONS}

The solvent was synthesized on the base of the waste alcohol fraction from Cyklopol process, which mainly consists of amyl - acetic acid ester. The fraction contained other agents: the esters of other alcohols present in the raw product and unprocessed substances. The result of the tests on the obtained solvent as a glue for plastics pointed out to the fact that this solvent can be more useful for sticking PMMA together. Slightly worse sticking properties in the case of PS, PET, PC and PVC were found out as well. The strength (shear) test proved that the proposed solvent glue is characterized by better sticking properties than those commercial glues for PMMA available on the market. The additional advantage of our glue is its pleasant fruity smell. The use of most commercial glues is connected with an unpleasant feeling caused by smell. It was found that there is the possibility of the utilization of waste alcohol fraction as a raw material for glue production in the way described in this work. The proposed esterification method may be a convenient way of utilization of waste alcohol fraction naturally occurring during cyclohexanone manufacturing.

\section{LITERATURE CITED}

1. Report of the European Parliament Commission "On the review of the Community strategy for waste management", COM (96)0399 final.

2. Ogonowski, J. \& Vogt, O. Plastyfikator do tworzyw sztucznych na bazie odpadowych frakcji alkoholowych, materiały VII międzynarodowej konferencji naukowej CLPO, 21 - 22.11.2002, (pp. $222-227$ ).

3. Vogt, O., Rakoczy, J., Ogonowski, J., Mizdra, M., Bisok, M. \& Nowak, D. Utilization of the waste fraction of monohydric alcohols for synthesis of a PVC plasticizer, Chim. i Chim Techn., 46, No 5, 2003 s. $100-103$.

4. Vogt, O. \& Stanisławczyk, A. Synteza związków powierzchniowo czynnych $\mathrm{w}$ oparciu o frakcję odpadowa $\mathrm{z}$ procesu Cyklopol, Przem. Chem., 84/3, 2005, s.197 - 200.

5. PN-76/C-04539, Rozpuszczalniki i rozcieńczalniki lakiernicze. Metody badan.

6. PN-EN 1392:2000. Kleje do skóry i materiałów obuwniczych. Kleje rozpuszczalnikowe i dyspersyjne. Metody badań wytrzymałości połączenia $\mathrm{w}$ określonych warunkach.

7. PN-EN 26922:2000. Kleje. Oznaczanie wytrzymałości na rozciąganie połączeń czołowych.

8. PN-EN 12003:1999. Kleje do płytek. Oznaczanie wytrzymałości na ścinanie klejów na bazie żywic reaktywnych. 